\title{
The Economics of Skills Obsolescence: a Review
}

Citation for published version (APA):

de Grip, A., \& van Loo, J. B. (2002). The Economics of Skills Obsolescence: a Review. In A. D. Grip, J. V. Loo, \& K. Mayhew (Eds.), The Economics of Skills Obsolescence: Theoretical Innovations and Empirical Applications (pp. 1-26). Elsevier Science. Research in Labor Economics No. Vol. 21 https://doi.org/10.1016/S0147-9121(02)21003-1

Document status and date:

Published: 01/01/2002

DOI:

10.1016/S0147-9121(02)21003-1

Document Version:

Publisher's PDF, also known as Version of record

\section{Please check the document version of this publication:}

- A submitted manuscript is the version of the article upon submission and before peer-review. There can be important differences between the submitted version and the official published version of record.

People interested in the research are advised to contact the author for the final version of the publication, or visit the DOI to the publisher's website.

- The final author version and the galley proof are versions of the publication after peer review.

- The final published version features the final layout of the paper including the volume, issue and page numbers.

Link to publication

\footnotetext{
General rights rights.

- You may freely distribute the URL identifying the publication in the public portal. please follow below link for the End User Agreement:

www.umlib.nl/taverne-license

Take down policy

If you believe that this document breaches copyright please contact us at:

repository@maastrichtuniversity.nl

providing details and we will investigate your claim.
}

Copyright and moral rights for the publications made accessible in the public portal are retained by the authors and/or other copyright owners and it is a condition of accessing publications that users recognise and abide by the legal requirements associated with these

- Users may download and print one copy of any publication from the public portal for the purpose of private study or research.

- You may not further distribute the material or use it for any profit-making activity or commercial gain

If the publication is distributed under the terms of Article $25 \mathrm{fa}$ of the Dutch Copyright Act, indicated by the "Taverne" license above, 


\section{THE ECONOMICS OF SKILLS OBSOLESCENCE: A REVIEW}

\section{Andries De Grip and Jasper Van Loo}

\section{ABSTRACT}

In this chapter we review the economic literature on the warious causes of skills obsolescence and the ways in which skills obsolescence has been modelled or estimated. Most of the literature focuses on skills obsolescence due to atrophy and worker displacements. Skills obsolescence nay, however, also be due to the wear of skills, technological and organizational developments, shifts in the structure of employmemt and organizational forgetting. In the second part of the chapter, we discuss measures for skills obsolescence. Skills obsolescence measures are related to both the cause of skills obsolescence and the way in which it mamifests itself.

\section{INTRODUCTION}

An important characteristic of the literature on skill-biased technological change is the focus on technological developments that increase the complexily of jobs in many different segments of the labor market (e.g. Groot \& De Grip, 1991; Machin \& Van Reenen, 1998; Wolf, 2000). These teclunological developments are often related to various organizational renewals that also have their effects on the skills demanded in various occupations (e.g. Bresnahan, Brynjolfsson, \& Hitt, 1999; Caroli, 1998). Apart from the apparent upgrading effect of the skill level demanded in the labor market, there are also shifts in the type of

The Economics of Skills Obsolescence, Volume 21, pages 1-26.

Copyright 2002 by Elsevier Science Ltd.

All rights of reproduction in any form reserved.

ISBN: 0-7623-0960-1 
skills demanded. In particular, problem-solving skills, communication and social skills and information technology (IT) skills are becoming increasingly important in many jobs (Green et al, 2000). Both the upgrading tendencies and the shifts in the types of skills demanded increase the awareness that in the "greying" western economies many workers run the risk of their skills becoming obsolete (e.g. National Skills Task Force, 1999).

Early human capital literature dealt with the issue of skills obsolescence by including the rate by which the stock of human capital deteriorates in determining the optimal path of lifetime investment in human capital (see e.g. Ben-Porath, 1967). Other disciplines also deal with the obsolescence of skills. The first mention of "occupational obsolescence" was probably made by Tugwell (1931b) in an article in Political Science Quarterly. Tugwell used the term "occupational obsolescence" as a better alternative for the term "technological unemployment," as "obsolescence impties that something has happened to outmode a particular way of doing," whereas "unemployment is far from being the whole problem." Moreover Tugwell states that separations of workers from their jobs are not merely due to technological developments, but may also be due to demand shifts on product markets.

In his paper in the American Psychologist, Dubin (1972) discusses the professional obsolescence of workers in terms of "the half-life of a professional," a concept taken from nuclear physics. The half-life of a professional can be described as "the time after completion of professional training when, because of new developments, practicing professionals have become roughly half as competent as they were upon graduation to meet the demands of their profession." Rosenow (1971) estimated the half-life of medical knowledge to be five years, whereas Lukasiewicz (1971) stated that the half-life of a 1940 engineering graduates was 12 years compared to five years for the graduates at the end of the 1960s.

As mentioned in Rosen's (1975) seminal paper on "Measuring the Obsolescence of Knowledge," from an economic point of view two main types of skills obsolescence can be distinguished. Analogously to economic theory with respect to the depreciation of physical capital, we can roughly distinguish between technical and economic skills obsolescence. Technical skills obsolescence is due to changes that originate in workers. Economic skills obsolescence, on the other hand, is caused by changes in the job or work environment (Neuman \& Weiss, 1995).'Technical skills obsolescence therefore affects the human capital of a worker itself, whereas economic skills obsolescence affects the value of the human capital of workers. Rosen (1975) refers to the former as the depreciation of human capital opposed to obsolescence related to the market value of a worker's human capital. 
In this chapter we review the economic literature on the causes of skills obsolescence and the various ways in which skills obsolescence has been modeled or estimated in both theoretical and empirical studies. For this review we develop a typology of the various types of skills obsolescence that can be distinguished with respect to the different possible causes of skills obsolescence. Apart from its analytical relevance a framework like this is also relevant from a policy point of view as it indicates the character of the training policy needed when workers are facing a particular type of skills obsolescence.

The chapter is structured as follows. Firstly, building on the main distinction between technical and economic skills obsolescence, in Section 2 we develop a typology of the different types of skills obsolescence at the individual and firm level and discuss the economic literature that is concerned with these types of obsolescence. In Section 3 we describe the state of the art with respect to the way in which skills obsolescence has been measured in the economic literature. Section 4 concludes and summarizes.

\section{CAUSES OF SKILLS OBSOLESCENCE}

From an economic point of view two types of skill obsolescence may occur. Human capital may depreciate due to technical and economic skills obsolescence. Technicall obsolescence affects the stock of human capital a worker possesses in the sense that skills get lost, whereas economic skills obsolescence affects the value of the human capital a worker possesses due to external developments.

Building on this main distinction, we develop a typology of five different types of skills obsolescence related to the cause of the obsolescence: two types of technical obsolescence and three categories of economic obsolescence. Firstly, the depreciation of human capilal may simply be caused by the wear of skills, resulting from the natural ageing process, injuries or illness. The second category of technical skills obsolescence concerns the atrophy of skills due to the lack of, or insufficient use of skills. This atrophy could result from unemployment, or from employees" working below their attained level of education. Also, as a result of speciallization certain knowledge and skills acquired during initial education may get lost.

Related to different causes of economic skills obsolescence three types of skills obsolescence can be distinguished. Firstly, job specific skills obsolescence may occur due to technological or organizational developments in the production process, which change the skills demanded for a particular job. In that case the skills the workers in that occupation possess are probably no longer sufficient to perform their jobs properly. A second type of economic skills 
obsollescence is related to the shifts in the sector structure of employment. In that case, workers' skills may still be adequate for their profession, but the demand for their occupation is declining. Shifts in the industry structure of employment can be due to shifts in consumer demand, investments, government purchases and international trade patterns. Due to these demand shifts part of the workers employed in sectors of industry, which face a sharp decline in employment have to find a job in another economic sector in order to remain employed. Finally, economic skills obsolescence may be due to firm-specific skills obsolescence. This may occur if workers are laid off in case of a firm closure or reorganization. In that case the firm-specific skills of these workers lose their value.

The above-mentioned types of skills obsolescence all refer to the individual level. However, as the counterpart of organizational "learning by doing" (Arrow, 1962) organizational forgetting may occur. This organizational forgetting is not merely the aggregate of the wear of skills of the individual workers in the firm. but may also be due to quits of workers with firm specific skills.

An overview of the various types of skills obsolescence discussed above is given in Table 1. This typology is especially relevant from a (human resources) policy point of view, since it might indicate the kind of training that is required when of workers face a particular kind of skills obsolescence. For example, in the case of wear and atrophy training policies should focus on refresher courses with respect to the skills that had gone lost or retraining if workers are no longer able to remain employed in their current jobs. In case of job-specific

Table 1. Types of Skills Obsolescence.

Type of skills obsolescence

Technancal skills obsolescence

- Waar

- Atropliny

Econtomic skills obsolescence

- Job-specific skills obsolescence

- Skills obsolescence by sectoral shifis

- Firm-specific sikills obsolescence

Organizational forgetting
Depreciation of human capital by:

Natural ageing process, illness, or miury

No or insufficient use of skills

New skill requirements due to developments in society

Shrinking employmant in occupation or economic sector:

External mobility

The aggregate of wear of skills of individual workers, or quits of workers with firm-specific skills 
skill obsolescence further training related to the new skills demanded in the current job are needed, whereas in case of skills obsolescence due to shifts in the sector structure of employment training policies should focus on retraining workers for another profession. If workers mainly face firm-specific skills obsolescence mobility to another firm and the related firm specific human capital investments should be facilitated.

As mentioned in the introduction both technical and economic skills obsolescence are recognized in early human capital literature. Moreover its impact on the optimall path of lifetime human capital investments has been considered. Ben-Porath (1967) simply models skill obsolescence as something that has a negative effect on the rate of change of the human capital stock, i.e.:

$$
\dot{K}_{y}=Q_{i}-\delta K_{t}
$$

where $\mathcal{Q}_{v}$ is the flow of human capital produced in year $t, K$, is the stock of human capital and $\delta$ is the rate by which the stock of human capital deteriorates.

In a similar way Rosen (1975) includes skill deterioration as an important correction to the measurement of the productivity effect of investments in training. Rosen argues that these investments should be considered gross investments in training. Depreciation should be taken into account to determine net training, which could add to a worker's productivity. As mentioned above Rosen recognizes the occurrence of both technical and economic skill obsolescence: "(apart from the skill acquired by experience) older persons possess less skill because they received less from their education (acquired at an earlier date) and also because what they did learn has depreciated over a longer period of time." (Rosen, 1975, p. 204).

However, the depreciation of human capital has never been in the core of the analysis. Labor economics particularly developed the insights in the production of human capital distinguishing between specific, general and transferable skills and the shifts in the educational structure of labor demand. Apart from the studies on the atrophy of skills due to career interruptions and the literature on job displacements, the obsolescence of skills has never been a major line of research in labor economics. Howewer, from warious points of view related to one or more of the possible causes of skills obsolescence mentioned above studies have been published. In the remainder of this section we will give an overview of this scattered literature.

\section{Technical Skills Obsolescence: Wear}

Rosen (1975) indicates the obsolescence due to the wear of skills as the depreciation of human capital, which depend on the age of persons: 
Depreciation arises because the ability of individuals to apply acquired skills and knowledge to income producing opportunities systematically changes with age.

On this point Rosen distinguishes between:

- the general deterioration of mental and physical capacities due to ageing and - the decreasing capacity to learn and adapt to new situations.

Strictly speaking, the latter does not refer to human capital that gets lost, but refers to a declining effectiveness of further investments in additional training or learning on-the-job.

Van Loo et al. (2001) argue that the wear of workers' skills is not only related to the natural ageing process. It may also be due to injury or illness. This means that physically or mentally heavy working conditions may accelerate the wear of a worker's skills. If e.g. a 40-year-old bricklayer is no longer able to use his vocational skills due to persisting back pains, his vocational human capital has been lost.

\section{Technical Skills Obsolescence: Atrophy}

In the economic literature, there have heen a number of contributions to the relation between the non-use of skills and atrophy. There are many underlying factors that could be responsible for a person not using specific acquired skills. The most important distinction that can be made is between atrophy that takes place when a person is employed on the one hand, but is not using all his or her skills in the current job and on the other hand atrophy taking place when employees are unemployed or have interrupted their career.

An example of the first type of atrophy is the suggestion of Freeman (1976) that knowledge is "wasted" when there is excess supply of higher educated people, forcing higher educated persons to apply for jobs that require fewer skills than they have actually obtained. Higher educated people then more or less automatically become under-utilized or overeducated. The skills and knowledge that these overeducated people do not apply in their job may decay or may even be lost completely.

Krahn and Lowe (1997) analyzed the atrophy of skills of employed persons. They studied the impact of spending an extended period of time in a job with limited literacy requirements on literacy loss over time. The results of their study support the idea that working in an environment with limited complexity leads to skill loss through atrophy.

Arthur et al. (1998) conclude, on the basis of a meta-analysis from the psychological literature on skill decay and retention, that there is substantial 
skills obsolescence when skills are not practiced or used. Analogous to these findings it seems plausible to suggest that spending time without a job may even cause a more severe degree of atrophy, since being out of a job implies that most skills are not used at all.

Several authors have addressed the issue of atrophy caused by career interruptions and periods of unemployment (Corocan \& Duncan, 1979; England, 1982; Kim \& Polachek, 1994; Mincer \& Ofek, 1982; Mincer \& Polachek, 1974; Mincer \& Polachek, 1978; Sandel \& Shapiro, 1980). Using U.S. data, these authors focus on career interruptions and unemployment duration and their effects on earnings and wages of female workers. All the studies find that time out from work has a negative effect on wages. Women who take time out appear to suffer an additional negative effect above and beyond the wages lost due to the fact that they do not build up further experience. This additional effect has been interpreted as the result of skill atrophy.

Mincer and Ofek (1982) present a graphical representation of the various (wage) effects of an interruption of a worker's career. As Fig. I shows the age-earning profille for a continuous worker is given by the straight line $J K L_{\text {w }}$ whereas the age-earning profile of a worker who faces a career interruption is indicated by the line $A B C D E F G$. The figure assumes that the career interruption is anticipated by means of a lower rate of investment in human capital, which is reflected in a relatively flat wage profile in the pre-interruption period ( $A B$ instead of $J K)$. At the re-entry point the wage $(D E)$ is below the wage at the point of labor force withdrawal $(C B)$, whereas $\beta$ is equivalent to the rate of depreciation due to lost experience. Mincer and Ofek (1982) qualify this as the short run rate of depreciation due to non-use $(\varepsilon), \varepsilon$ is reduced in the long run to $\delta$ due to the restoration of market productivity and the accumulation of job tenure in the post-interruption period.

Mincer and Polachek (1978) and Polachek (1981) were among the first to measure an occupational rate of atrophy. They detined atrophy as the loss of earnings potential that can be attributed to periods of work intermittency and argued that the occupation in which the loss of earnings potential is smallest the atrophy rate is lowest. The authors obtained estimates of atrophy rates from regressions of first differences in wages on length of work interruption for each broad occupational category during the years 1967-1972. They found that the atrophy rate is highest for professional, craft and managerial occupations and (logically) lowest for unskilled and household labor. On the basis of these findings Polachek (1981) concludes that women often avoid work in professional, craft and managerial occupations because of the high atrophy rate in these occupations. However, England's (1982) research on occupational sex segregation does not support these findings (see Section 3 ). 


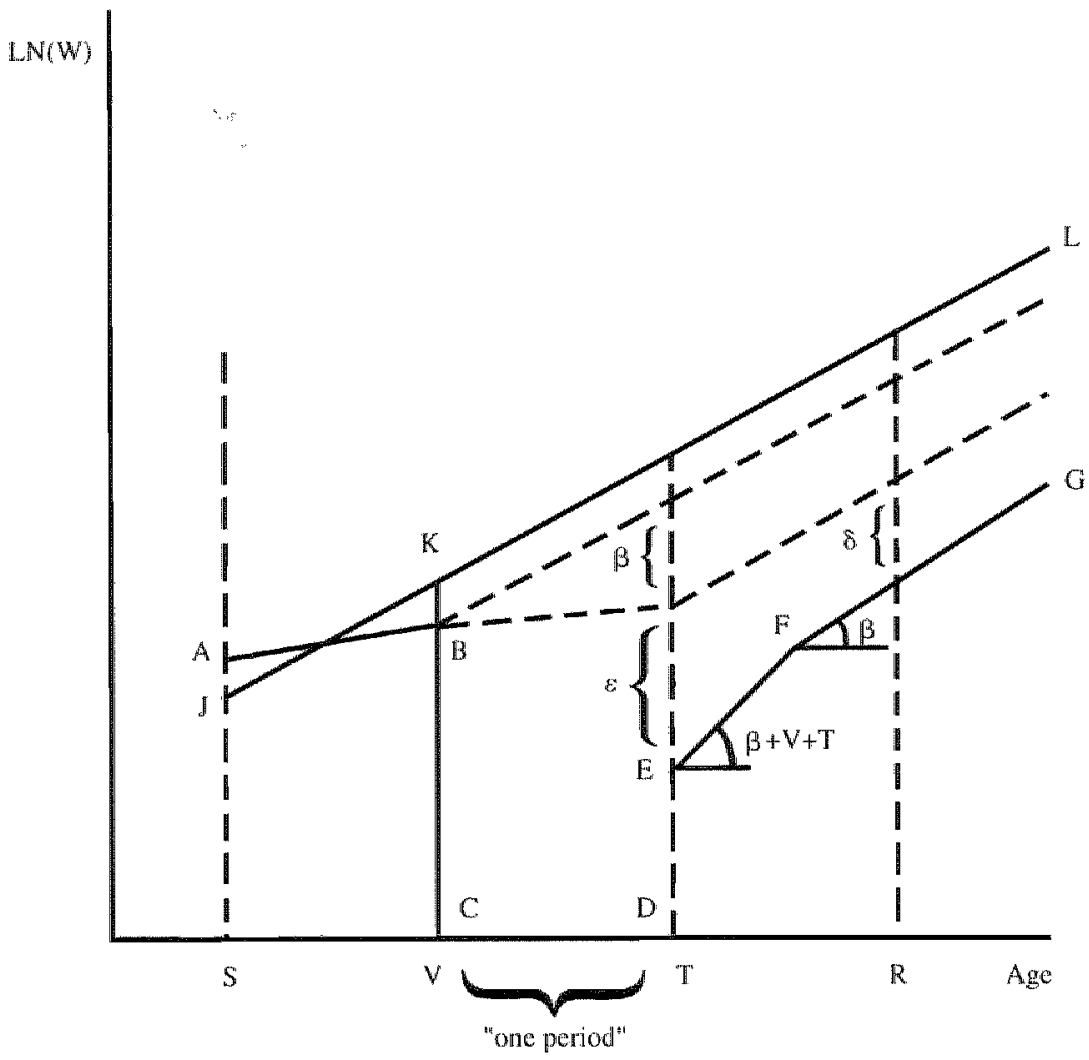

Fig. l. Age-earning Profile in Case of a Career Interruption.

Sonrce: Mincer \& Orek (1982).

Mincer and Ofek (1982) studied the depreciation and restoration of human capital and they too concluded that dropping out of the labor force for a period of time results in the depreciation of skills and a significantly lower rate of return to a given number of years of work experience. A recent study on technological change and skills obsolescence in Germany by Blechinger and Pfeiffer $(2000)$ also confirms these results by showing a decrease in monthly gross earnings by $9 \%$ if a person re-enters after a period of unemployment. Temporarilly interrupting the career even reduces monthly gross earnings by no less then $12 \%$. The authors further suggest that after a period of unemployment, re-entering the labor market leads to jobs allowing for less utilization of skills obtained earlier, which would cause further skills atrophy. Albrecht et al. (1999) 
use a rich Swedish data set to re-examine the effects of time out on subsequent wages and find that, consistent with U.S. studies mentioned earlier, total time out has a significant negative effect on both women's and men"s wages. However household time and unemployment duration have significant negative effects on women's wages, while formal parental leave has no effect at all. Men, on the other hand, are confronted with a significant negative wage effect from formal parental leave. The results of this study suggest that the drop in wages associated with time out is not mainly due to skill atrophy, because if that were so time out should have similar effects.

Although focusing on the effect of "forgetting" on a firm's learning curve, in his experimental study Bailey (1989) also analyses the effect of atrophy on the effects of an interruption of the learning process. From the relevant psychological literature he introduces the important distinction between "continuous controll tasks" and "procedural tasks." Continuous control tasks involve repetitive movements without a clear beginning or end, for example visually inspecting parts on an assembly line. Procedural tasks consist of a series of discrete simple motor responses, such as pressing appropriate buttons to run a computer. Thus a procedural task consist more of learning what to do than of learning the motion itself. Bailey shows that forgetting of a continuous control task is negligible, whereas forgetting a procedural task is a function of both the time of interruption and the amount of learning before the interruption.

\section{Economic Skills Obsolescence:}

Technological and Organizational Developments

As mentioned in the introduction, skills obsolescence due to rapid technological developments is most prominent in the current public debate on the necessity of lifelong learning. However, studies in this field are still scarce, although we can find notions of skill obsolescence due to technological developments in the economic literature at the beginning of the past century. In his article on "Machinery and the Laborers" in the Quarterly Joumal of Economics of 1908 Carver (1908) argued that "the progress of invention has caused a shifting demand for the services of the different classes in the industrial world" Manual workers are less important but "engineers and others who supply certain types of labor, are becoming relatively mone important."

The main focus in the early literature in this field is on the "substitution of improved machines and processes for men." In this respect Tugwell (1931a, b) introduced the term "occupational obsolescence" instead of the more common notion of "technological unemployment." This change in emphasis reflects the notion that it is "impossible and undesirable to prevent (technological) change." 
The main problem is therefore "that workers, once replaced, will have difficulty" finding jobs for which they have been trained." The best solution for this problem "could be found in the direction of adult education and the rehabilitation of the human obsolescen" (Tugwell, $1931 \mathrm{~b}$ ).

Earlly human capital literature also dealt with skill obsolescence due to technological change (e.g. Cipriani, 1967; Holtmann, 1972; Rosen, 1975). Holtmann (1972) and Weisbrod (1962) argue that by investing in education individuals may gain "secondary skills to maintain options against technological absolescence" (Holmann, 1972, p. 414). This also holds for investments in training: "the firm can reduce the rate at which benefits deteriorate by making investments in the worker's original training. Differential returns to various amownts of training are atributable to the decrease in the rate of obsolescence of present training and the decrease in the rate of obsolescence of all future training." (Holtmann, 1972, pp. 414-415). However, the mechanisms by which initial education and training reduce the rate of skill obsolescence are not made very explicit. Most clearly stated it is defined as the option value of education, i.e. the "secondary skills"s that enable workers to remain productive if firms change the technology of the production process. For Holtmann this option value of education is more or less synonymous with the "quality of training." Mincer (1989) links skills obsolescence to the incentive to invest in training. II., due to technological developments, "the skills acquired in training become rapidly obsolete, the incentives to invest in training would be reduced. However, if obsolescence is gradual or partial, successive training would add to skills, and incentives would not be impaired, especially if employers share the training costs." (Mincer, 1989, p. 13)

Su (1973) simply defines skills obsolescence due to technological change as the gap between what a worker already knows and what he needs to know for working with the new technology. Following Holtmann (1972), he assumes that this gap is smaller for workers with a higher quality of initial education, since a higher quality of initial education reduces the retraining costs later in a worker"s calreer. Su also gives the condition for the optimal point in time at which a firm terminates the retraining of existing workers and starts hiring new workers: "Given the quality of workers, the firm should continue training until the benefit net of labor costs per worker per unit of time is equal to the marginal rraining costs." (Su, 1973)

Rosen (1975, pp. 199-200) considers the obsolescence of skills due to technological developments to be a vintage effect:

Obsolestence occurs because stocks of knowledge available to society change from time to time... Sometimes new knowledge proves received knowledge to be incorrect or at least lessi general than was supposed at an earlien time. Similarly, production innovations often 
render useless skills associated with prior methods. In both cases, capital losses are innposed on those embodying the earlier knowledge and skills.

Apart from this effect of technological developments on the skills demanded in the labor market, Rosen (1975) also points to the effect innovations in teaching methods may have. If these innovations make the learning process for particular skills more productive, these innovations will increase value added from given resource inputs. This will reduce the costs of learning and therefore the equilibrium price of these skills in the labor market.

Van Imhoff (1988) models the negative effect of a greying labor force on economic growth by means of a vintage model which takes account of skills obsolescence due to technological developments. He shows that when population growth slows down adult education becomes necessary to prevent the diffusion of technological innovations in the production process becoming hampered by the obsolescence of the skills of the working population.

Bartel and Sicherman (1993) focus on the ways in which technological change affects the retirement decisions of older workers. They argue that technological change can affect retirement decisions as it increases the depreciation rate of workers" human capital. However, technological change may also have a reverse effect on retirement as it induces workers to inwest more in additional training. Bartel and Sicherman therefore expect that in industries with high rates of technological change workers will retire later because of their investments in on-the-job training. However, an unexpected technology shock will induce older workers to retire sooner as in that case the required amount of training will be unattractive for older workers. Bartel and Sicherman's hypotheses are supported by their empirical results.

Neuman and Weiss (1995) further dewelop the analysis of the vintage effect of buman capital depreciation. They distinguish between the depreciation of skills due to wear and the depreciation of human capital because the skills workers learned at school have become more or less outdated. They state that this is dependent on the level of schooling. Contrary to Holtmann (1972) and Cipriani (1967) they assume that the higher the level of education of a worker, the more quickly the human capital becomes obsolete. Since the material taught in elementary schools does not change much over time. Neuman and Weiss (1995) assume that workers with only elementary school hardly suffer from any skill obsolescence.

Figure 2 illustrates the assumed experience-earning profiles for workers with different vintages of education by level of education $(16,12$ and 8 years of schooling, respectively). Each curve shows the experience-earning profile for a certain time-equivalent level of education. The year shown on each curve is 


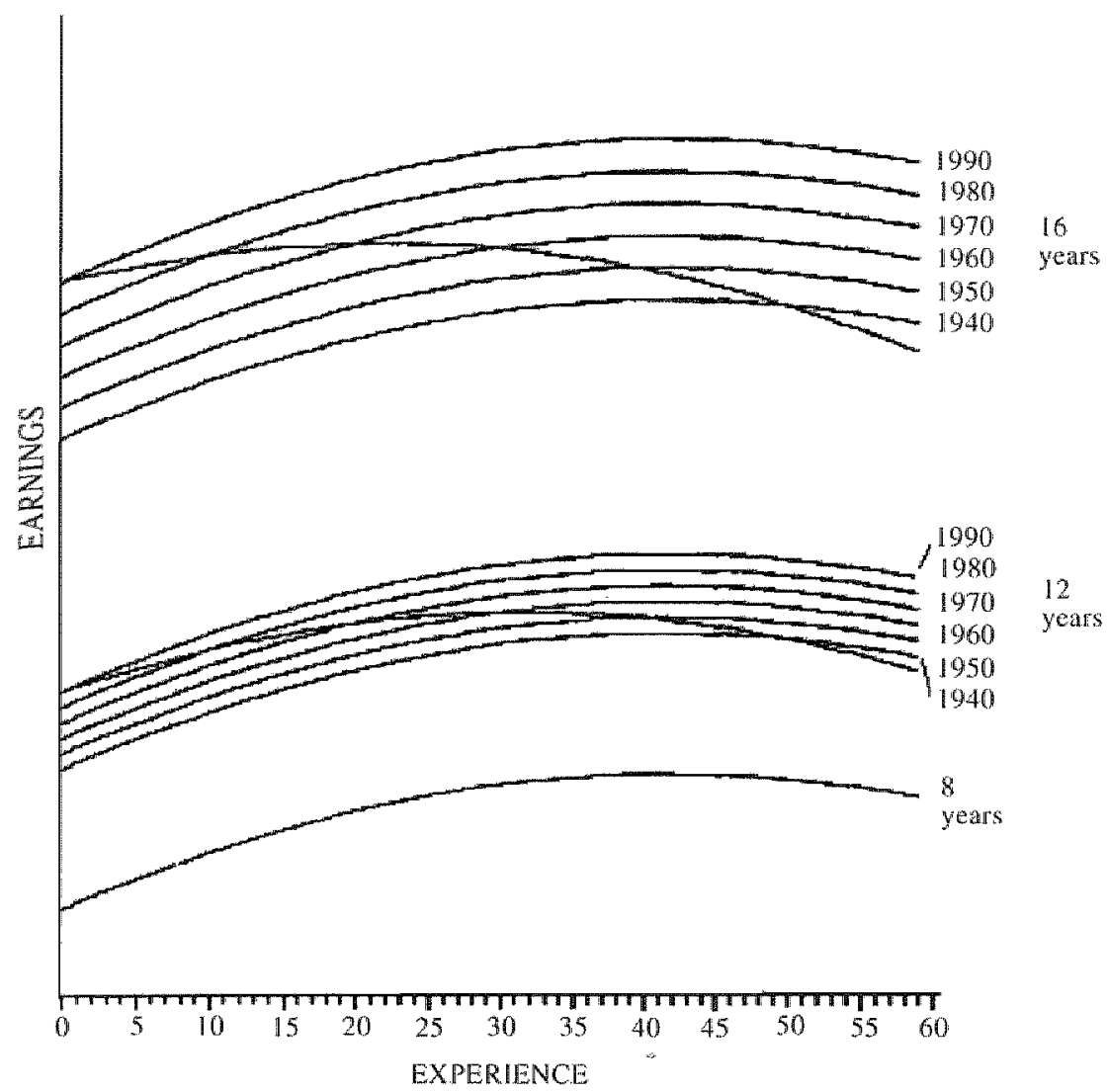

Fig. 2. The Effect of Schooling Vintage on Experience-Earnings Profiles. Sounce: Neuman \& Weiss (1995).

the year in which schooling was completed. For example college graduates that have just graduated are on the upper curve (1990). Someone who finished initial education in 1980 is on a lower curve because his vintage of schooling is less productive than the more recent vintages. However, given further depreciation 10 years later he will be on the 1970 curve. The dark line in the figure shows the experience-earnings profile of an individual graduate in the course of his lite.

The hypothesis of skills obsolescence because of technological developments is related to the literature on skill-biased technological change (SBTC), which 
points to the upgrading of the skill level demanded due to technological developments. This means that more highly educated people will be employed in occupations that used to be the domain of low-skilled workers. New technologies have in fact opened up possibilities of utilizing the skills of high skilled workers productively in these occupations, whereas the skills of the lower educated workers who used to work in these occupations are no longer sufficient to remain employed in their jobs (Borghans \& De Gtip, 2000).

Autor et al. (1998) show that the upgrading of the skill level of the workforce is the strongest in the most computer-intensiwe sectors. As mentioned in the introduction, advances of ICT inducing an upgrading of the skill level demanded in a job, are often complementary with organizational changes that enable firms to improve their service quality:

Effective use of computer systems calls for new cogative skills, having a deep understanding of one's own organzation and one's customers" needs. Even those managerial and protessional workers who never touch computers are having their work tratsformed in this way, calling for more and more complex bodies of skill and knowledge (Bresnahsn et al., 1999).

Apart from the upgrading of the level of skills demanded in many jobs, technological developments also affect the kind of skills demanded. A typical example of skills obsolescence due to technological developments is the introduction of personal computers in an office environment. This innovation decreased the value of basic typing skills, one of the main competences demanded in the work of secretaries. Instead knowledge of Windows-based software has become more important for their productivity. In particular, problem-solving skills, communication and social skills and computing skills are becoming increasingly important in many jobs, whereas the market price of manual skills declines (Green et al., 2000). These shifts in the skills demanded in many jobs are often related to the organizational changes that accompany the diffusion of $\mathbb{I C T}$. This in particular holds for the increasing demand for workers with both cognitive and "people skills" (Autor et al., 1998).

Moreover, organizational devellopments such as reorganizations and changing management systems can have a dramatic influence on the content of jobs (Caroli. 1998; Van Loo et al., 2001; Watkins \& Marsick, 1993). Particularly. the shift from intensely specialized mass production towards modes of production that focus on tailor-made products requires more flexible and multi-skilled workers (cf. Lindbeck \& Snower, 2000). These developments depreciate the market value of the human capital of the more specialized workers who were used to work in more traditional modes of production.

Economic literature has also paid attention to the differences in the durability of skills in various fields of expertise. McDowell (1982) shows that 
knowledge in physics and chemistry becomes more rapidly obsolete than in humanities. For this reason the latter studies are much more attractive for women who anticipate on a career interruption for the purpose of raising children.

Economic Skills Obsolescence:

Shifts in the Sector Structure of Employment

The notion that skill obsolescence could occur due to demand shifts in product markets also goes back to the early literature on the shifts in the sectorall structure of employment. Tugwell (1931a) argues that a worker who faces skill obsolescence should be retrained for "expanding and needed activities in the place of his own vanishing one."

A seminal article on the shifts in the sectoral. structure of employment is Lilien's (1982) paper in the Joumal of Political Economy on Sectoral Shifts and Cyclical Unemployment. Lilien focuses on defining the natural rate of unemployment due to the reallocation of workers required by the sectoral shifts in employment and does not refer to any notion of skill obsolescence. However, apart from frictional search unemployment, skills obsolescence is probably part of the problem if shifts in the sector structure of employment cause temporary unemployment of workers in declining sectors of industry who have to search for a job in another industry in which the demand for labor increases.

Skills obsolescence due to shifts in the sector structure of employment is related to Wood's notion (1994) that in the global process of specialization the western economies specialize on the knowledge intensive "high tech" sectors of industry, whereas sectors in which traditionally many low-skilled workers are employed move to the less advanced economies. For low-skilled workers this implies that their employment opportunities shift from the "open" manufacturing sector to service sectors, which cannot move abroad, such as personal and consumer services. This probably implies that low skilled workers who were employed in manufacturing should acquire more communication skills. Moreover, the human capital of these workers that is specific to the occupation or sector of industry in which they were employed loses its market value ( $\mathrm{Van}$ Loo et al., 2001).

As Kletzer (1998, p. 129) argues, displaced worker studies (see below) revealed that the sector of industry in which a worker is employed is an important dimension across which skills are transferable: "the post-displacement earnings of individwals who change industry are lower than the eamings of otherwise comparable individuals who stay in the same industry." 


\section{Economic Skills Obsolescence: Firm Specific Obsolescence}

Davis et al. (1996) emphasizes the importance of the continuous reallocation of jobs between firms. They show that (gross) job creation and destruction is much larger than suggested by the figures on the (net) increase or decrease of employment by sector. The high level of reallocation of jobs between individual firms can be a major source of skill obsolescence. As already noticed by Beveridge (1930, p. 17), particularly workers who heavily invested in firmspecific human capital therefore run the risk that their human capital becomes obsolete:

The men peculiarly liable to this complete reversal of fortune are those who, without being in the ordinary sense slitlled, acquire by prowe trustworthiness. by familiarity with the course of business ... a spexial value for one employer but who when that employment fails cannot prove their worth to another.

The notion of firm-specific skill obsolescence is also found in the literature on job displacement. Hamermesh (1987) found that displaced workers face a considerable loss of their "job-specific" human capital, as reflected in their post-displacement wage level. By focusing on "mass layoff separations." Jacobson et al. (1993) sharpen the focus on the workers for whom the previous employment relation was valuable. Their analysis showed that mass layoffs cause large losses of firm-specific human capital. Carrington (1993) emphasizes the large losses of firm-specific human capital when workers with long tenures are displaced even when the local labor market is performing well.

\section{Organizational Forgetting}

In contrast to the various types of skill obsolescence dealt with above, "organizational forgetting" does not refer to skill obsolescence faced by individual workers. As a matter of fact it is the counterpart of Arrow's (1962) "learning by doing." As mentioned above, Bailey (1989) implicitly interprets organizational forgetting as the aggregate of the wear of skills of the individual workers in a firm. Darr et al. (1995), however, argue that the knowledge acquired by learning by doing may also be lost by personnel turnover. In their study on pizza stores they find that the knowledge acquired by learning by doing depreciates rapidly. They argue that high turnover rates of employees are a major cause of organizational forgetting in service organizations.

Studies on organizational forgetting show that the rate of organizational forgetting in fast food franchises is much higher than in shipbuilding, whereas organizational forgetting in automotive production is lower than in shipbuilding 
Table 2. Owerwiew of Studies on Skills Obselescence.

\section{Technical skils Obselescence}

Wear

Rosen (1975). Wan Loo at al. (2001)

Alrophy

Mincer and Polachek (1974), Freeman (1976), Mincer and Solamon (1978), Corocan and Duncan (1979). Sandel and Shapiro (1980). Polachek (1981), England 1982). Mincer and Ofek (1982), McDowell (1982), Babley (1989). Kim and Polacheck (1994), Krahn and Lowe (1997). Albrecht all. (1999), Blechinger and Pfeiffer (2000), Van Loo et al. (2001)

\section{Economic skills obsolescence}

Technologitical and organizationd developmens

Cipriani (1967), Holtmann (1972, 1973), Su (1973), Rosen (1975), Van Imhoff (1988). Mincer (1989). Groor and De Grip (1991), Bartel and Sicherman (1993), Nehman and Weiss (1995). Blechinger and Pfeiffer (2000), Van Loo et al. (2001)

Shifts in whector structwe of employnent

Tugwell (1931a., 1931b), Lilien (1982), Wood (1994), Kletzer (1998), Wan Loo et al. (2001)

Finw specific skills obsolescence

Beveridge (1930), Hamermesh (1987). Addison and Portugal (1989). Carrington (1993), Jacobson et all. (1.993), Kletzer (1998), Van Loo et al. (2001)

\section{Organtitational forgetting}

Keachie and Fontana (1966), Bailey (1989), Argote at al. (1990), Epple et al. (1991), Darr et all. (1995)

(Argote et al., 1990; Epple et al., 1991). From these findings Darr et al. (1995) conclude that the slowest rates of depreciation are observed in technologically sophisticated production processes in which the knowledge is embedded in the technology of production. This knowledge is more resistant to depreciation than knowledge embedded in individual workers or in other aspects of the organization.

Table 2 gives an overview of the various studies on types of skills obsolescence discussed above.

\section{THE MEASUREMENT OF SKILLS OBSOLESCENCE}

In this section we will discuss the ways in which the various kinds of skills obsolescence outlined in Section 2 have been measured in the relevant literature. However, simillar to the difficulty in measuring workers' skills (Borghans et al, 2001; Van Loo \& Semeijn, 2001) the measurement of skills obsolescence is 
far from straightforward. Moreover, it is obvious that there is a distinction between, on the one hand, the measurement of technical skills obsolescence, related to the wear or atrophy of the skills previously possessed and, on the other hand the measurement of economic skills obsolescence which does not affect workers" skills but the market walue of these skills. Furthermore, it should be noticed that skills obsolescence can manifest itself in several ways, most of which were mentioned by Tugwell (1931b):

- unemployment;

- degradation to lower skilled jobs;

- lower wages;

- problems to fulfil one's job properly.

Generally speaking, four major forms of measuring skills obsolescence can be distinguished:

- objective methods: testing the deterioration of the skills workers possess;

- subjective methods: asking workers (and/or their employers) whether they face skills absolescence;

- (indirect) measurement of productivity: wages or eaming profiles or the unit costs of production:

- indirect measures: rate of innovations indicating the speed of skills obsolescence.

Most prominent in economic literature is the measurement of skills obsolescence by means of the workers' wages or earning profiles building on the framework that human capital theory offers. However, several studies rely on one of the other ways of measurement. As mentioned above skills obsolescence may be revealed in various ways, although it may be expected that in most cases the obsolescence of workers' skills will ultimately be reflected in their earnings. Moreover, as mentioned in Section 2, from a training policy point of view it is also relevant to distinguish between the different kinds of skills obsolescence that can be distinguished. This also affects the reguirements a proper measurement of skills obsolescence should fulfill.

\section{Wage Effects in Eaming Functions}

In the economic literature skills obsolescence is usually measured via workers' wages. This is the case for the literature on atrophy due to career interruptions (e.g. Mincer \& Ofek, 1982) as well as the literature on skills obsolescence due 
to technological developments (Neuman \& Weiss, 1995) and the literature on the obsolescence of sector-specific or firm-specific human capilal due to worker displacement (e.g. Jacobson et al., 1993). All these different types of skills obsolescence are measured by estimating eamings functions that take account of the particular kind of skills obsolescence concerned.

Following the arguments presented in Fig. 1. Mincer and Ofek (1982) estimate both the short-term and long-term wage loss due to the atrophy of a worker's skills caused by interrupted work careers. They estimate various specifications of earning functions that take account of the wage effects of both the periods of labor force participation and non-participation in a worker's career.

Neuman and Weiss (1995) estimate "Mincerian" earning functions in which they focus on the expected stronger skills obsolescence due to technological developments the workers employed in "high-tech" sectors of industry face.

Jacobson et al. (1993) define displaced workers" earnings losses to be the difference between their actual and expected earnings had the event that led to their job losses not occurred. They argue that this measure is better than comparing workers" wages in some post-displacement period and their earnings in a period shortly before separation. Firstly, the latter measure does not control for macro-economic developments that change workers" wages whether they are displaced or not. Secondly, it does not control for the wage growth that may have occurred when the worker was not displaced. Finally, the wages of displaced workers who were employed in firms that faced declining employment might have been adversely affected several years before these workers actually lost their jobs.

Greenhalgh and Stewart (1987), Lillard and Tan (1992), Lengermann (1996) and Arulampalam et al. (1.997) examine the effects of different types of training, distinguished by their timing. All four studies show that older spells of training are associated with smaller wage effects than more recent raining. This indicates the depreciation of the human capital not recently acquired. Greenhalgh and: Stewart, moreover, find that longer spells of training show less obsolescence than shorter spells and both Greenhalgh and Stewart and Arulampalam et al. find that the more general human capital acquired by non-vocational education does not face any obsolescence.

Of course, the key difficulty in measuring the wage effects of skills obsolescence is to isolate this effect from the effects of other factors that infuence workers' wages. Jacobson et al. (1993) and Kletzer (1998) argue that larger earning losses for displaced workers who change industry do not necessarily reflect the loss of sector specific human capital as industry wage effects may also be due to efficiency wages, union rents, incentive pay schemes, or internal labor markets. 
A similar point can be found in England's (1982) critique on Polachek"s measure of skills atrophy, namely the effect of post-school years of home-time on current eamings. England states that Polachek's measure is not a net measure of depreciation, because it also picks up some effect on earnings caused by foregone appreciation through experience.

It is difficult to distinguish between the wage effects of different causes of skills obsolescence. Rosen (1975) and Weiss and Lillard (1978) state that it is impossible to disentangle obsolescence of human capital due to wear and obsolescence due to technological developments since newer vintages enter and workers get older simultameously. However, Neuman and Weiss (1995) separate these two types of skills obsolescence in the experience-earning functions they estimate by assuming that skill obsolescence due to wear is the same across industries. This assumption can be justified by the fact that skill obsolescence due to wear is related to the worker himself and not to the industry in which he is ermployed. Following Mincer (1974), Neuman and Weiss include schooling vintages, measured as a worker's age minus years of schooling minus six the age at which schooling begins) in the earnings function. Assuming that the higher a worker's level of education the more quickly his human capital becomes obsolete, they are able to test whether technological developments cause skill obsolescence by means of the interaction term of experience $\times$ years of schooling. As mentioned above, Neuman and Weiss also distinguish between high-tech and low-tech sectors of industries, which enables them to test the hypothesis that skill obsolescence due to technological developments is faster in high-tech industries by means of the interaction term of high-tech $x$ experience $\times$ years of schooling.

\section{Other Measures of Productivity}

In the literature on organizational forgetting dealing with skills obsolescence at the firm level the loss of productivity is measured as the effect of the depreciation of knowledge on the unit costs of production (Darr et al., 1995). The effect of organizational forgetting on the unit costs of production is estimated with both past output and recent output at the right-hand side of the equation. In case of depreciation recent output is a more important predictor of current productivity than past output. The analysis of Darr et al. includes the possible obsolescence of all three knowledge variables related to learning by doing: i.e. firm specific experience, experience by the same franchisee and industry experience.

Minimum wages, union power or other barriers to downward flexibility of wages could imply that workers who face skills obsolescence will not be employed at a lower wage rate. This means that their skills obsolescence will 
be reflected in a higher risk of unemployment. For this reason Van Loo et al. (2001) use the flow from employment to unemployment or non-participation as an indicator of skills obsolescence."

\section{Objective Measurement: Tests of Workers" Skills Deterioration}

Although hardly used in economic literature it should be noted that the skills of workers can also be measured by means of testing or assessments. If such tests are repeated after some time in a longitudinal panel they can also measure skill obsolescence. Using the data of the OECD Imternational Adult Literacy Survey Leuven et al. (2000) show that measurements of the literacy skills of workers are probably a better measure of their skill levels than data on the level of education. Building on the extensive psychological literature on the measurement of intelligence and skills, (Bailey, 1989) shows how effective experiments in which individuals have to work at repetitive tasks can be applied for testing the wear of skills acquired by learning by doing.

\section{Subjective Measurement: Workers' and Employers Surveys}

Subjective measurement of skill obsolescence is also rare in economic literature. In their research on the obsolescence of skills acquired by apprenticeship training, Blechinger and Pfeiffer (2000) use survey data on the following question: "How much of the occupational knowledge and skills you acquired during your apprenticeship cam you still apply in your curreni work?" The answers are given at a five-points scale from "very little or nothing at all" to "very much." Blechinger and Pfeiffer show that these subjective measurements of the applicability of workers" previous apprenticeship training have some additional explanatory power in a standard Mincerian earnings function with experience and schooling. Particularly, the workers who could apply "very little or nothing at all" from their previous apprenticeship training have considerably lower wages than simillar workers with better applicability of their apprenticeship skills.

Van Loo et al. (2001) use a subjective measure for job-specific skills absolescence due to technological and organizational developments. People were asked to indicate whether or not their qualifications have depreciated due to changes in their current job. Van Loo et al. notice that it may be a disadvantage of this measure that it fails to take into account skills obsolescence, which is not perceived by the employees themselves. On the other hand a subjective measure of skills obsolescence may reveal skills obsolescence, which 
is not (yet) reflected in workers" earnings due to union power, internall labor markets or other institutions that cause wage rigidity.

Van Loo et al. (2001) also use a second suljjective measure of skills obsolescence based on a survey of employees. In this bi-annual survey, workers are asked to estimate the extent to which their qualifications are suited for their current job on a five-point scale. If between two points of time workers indicate a two-point or larger decrease in the score, this indicates that their qualifications have become less suited for the job they currently have. This can be interpreted as the occurrence of skills obsolescence.

\section{Indirect Measures}

McDowell (1982) uses a more indirect measure of skill obsolescence. He focuses on the rate at which a worker"s knowledge in a particular field becomes obsolete as refiected in the age profile of cited works: "The observation that older papers are less frequently cited than more recent papers suggests that, as research communications age, they lose some of their relewance in the current research front." (McDowell, 1982, p. 755). For his measure of the durability of knowledge McDowell uses the proportion of total citations in professional journals that are referenced to publications that were published within the five-year period immediately preceding the year of citation. The higher this literature decay rate, the higher the rate at which the knowledge in a particular field becomes obsolete. It should be noted, however, that such a measure of the durability of knowledge is of course quite related to other more indirect measures of the speed of technological developments as e.g. R\&D or ICT investments, which are usually seen as explanatory wariables for the way in which individuals in a particular segment of the labor market are facing skill obsolescence due to technological developments.

As mentioned in Section 2, Van Loo et al. (2001) allso relate the wear of worker's skills to injury or illness due to physically or mentally heavy working conditions. For this reason they discuss various measures of wear related to heavy working conditions. In their empirical analysis they use long-term job related sick leave as an indicator of wear that depreciates the vocational human capital of workers because they will probablly no longer able to retum to their previous job.

\section{CONCLUSIONS}

In this chapter we have attempted to give an overview of the different kinds of skills obsolescence that could analytically be distinguished with a major 
distinction between techmical and economic skills obsollescence. Apart from the literature on the atrophy of skills due to non-participation and the literature on job displacement, the literature on skills obsolescence is remarkably scarce. However, scattered studies on different aspects of skills obsollescence have been published. Most of these studies were published in periods in which unemployment was high. This increased the focus on the adverse impact of skill obsolescence for the worker involved. It is interesting that in the recent policy debates on skills obsolescence and "lifelong leaming" the main focus is on the waste of valuable human resources (in case of non-participation) and on the non-optimal performance of workers with inadequate skills due to skills obsolescence. This holds both for technical and economic skills obsolescence. This brings skills obsolescence to the heart of the economic challenge the western economies face: to realize the transformation towards a knowledge-based society with a greying population.

Therefore, further research in this field is of great importance. This holds for both the further development of theoretical insights and models and empirical research with respect to the various types of skills obsolescence distinguished. Moreover, economic analyses should more explicitly focus on the kind of skills involved in a worker's skills obsolescence and the rates at which the various kinds of skills become obsolete.

The latter requires that more adequate data on the development and obsolescence of skills should be developed by surveying or "testing" workers skills in surveys among workers. In this light the Intemational Adul Literacy Survey/Life Skills survey of the OECD and the Skills Survey of the Employed British Workforce (Green et al., 2000) are valuable initiatives. Moreover, it is important to develop linked employer-employee (LEE) data in which information on the skills obsolescence workers face can be related to information at the firm level on the diffusion of technological innovations and HRD-policies. Information on these issues is not only useful from a research point of view, but also from a policy point of view.

Finally, economic analysis should more explicitly focus on the effects of training or other HRD policies on the prevention or reduction of the various kinds of skills obsolescence that can be distinguished. In an era of rapidlly changing work in turbulent labor markets, skills obsolescence will likely gain importance on policy makers' agendas.

\section{NOTES}

1. Van Loo et al. (2001) use this measure of skills obsolescence in an empirical analysis in which they try to explain the occurrence of skills obsolescence due to market 
developments or firm-specific absolescence. However, the risk of unemployment is not necessarily restricted to these kinds of skills obsolescence.

2. For both variables the authors use of the Dutch labor supply survey of the Organization for Labor Research (OSA).

\section{REFERENCES}

Addison. J. T., \& Portugal, P. (1989). On the Costs of Worker Displacement: The Case of Dissipated Firm-Specific Training Investments. Sowthern Economic Joumal, 56, 166-182.

Albrecht, J. W.. Edin, P.. Sundstrom. M.. \& Vroman, S. B. (1999). Career Interruptions and Subsequent Earnings: A Reexamination Using Swedish Data. The Joumal of Hwhan Resources, 34(2), 294-311.

Argote, L. Beckman, S., \& Epple, D. (1990). The Persistence and Transfer of Learning in Industrial Settings. Management Science, 36, 340-352.

Arrow, K. (1962). The Economic Implications of Learning by Doing. Review of Economic Studies (June).

Arthur. W. J. Bennett, W. J., Stanush, P. L., \& McNelly, T. L. (1998). Factors that Influence Skill Decay and Retention: A Quantitative Review and Analysis. Human Performance, Il(1). $57-101$.

Arulampalam, W., Booth A. L. \& Elias P. (1997). Work-Related Training and Earnings Growth for Young Men in Britain. Research in Labor Economics, 16, 119-147

Autor, D. H. Katz, L. F., \& Krueger, A. B. (1998). Computing Inequality: Have Computers Changed the Labor Market? Quarterly Joumal of Economics, 113, $\| 169-1213$.

Bailey. C. D. (1989). Forgetting and the Learning Curve: A Laboratory Study. Management Science, $35,340-352$.

Bartel, A. P., \& Sicherman, N. (1993). Technological Change and Retirement Decisions of Older Workers. Joumal of Labor Economics, 11. 162-183.

Ben-Porath, Y. (1967). The Production of Human Capital and the Life Cycle of Earnings. Joumal of Political Econowy. 75, 352-365.

Beveridge, W. H. (1930). Unemployment, A Problem of Industry. London: Longmans, Green \& Co.

Bleclunger, D., \& Pfeiffer, F. (2000). Technological Change and Skill Obolescence: the Case of German Apprenticeship Training. In: H. Heijke \&J. Muysken (Eds). Education and Training in a Knowledge-Based Economy (pp. 243-276). Houndsmills/London: Macmillan.

Borghams, L., \& De Grip. A. (2000). Skills and Low Pay: Upgrading or Over educalion? In: M. Gregory \& W. Salwerda \& S. Bazen (Eds), Labor Market Inequalities. Problems and Policies of Low-Wage Employmen in International Perspective (pp. 198-223). Oxford: Oxford Universiry Press.

Borghans, L., Green, F., \& Maylhew. K. (2001), Skill measurement and economic analysis: an introduction. Oxford Economic Papers. 53(3) 375-384.

Bresnahan, T. F., Brynjolfsson, E., \& Hirt. L.. M. (1999). Infoxmation Techology, Workplace Organizarion and the Demand for Skilled Labor: Firm Level Evidence (NBER Working Paper 7136). Cambridge, MA. National Bureau of Economic Research.

Caroli, E. (1998). Technical Change. Work Organisaltion and Skills: Theoretical Background and Implications for Education and Training. In: CEDEFOP (Ed.), Traiming for a Working Sociefy (pp. 102-113). Luxembourg: CEDEFOP. 
Carringion, W. J. (1993). Wage Losses for Displaced Workers: Is it Really the Firm that Matters? Jownal of Homati Resources. 20, 435-462.

Carver, T. N. (1908). Machinery and the Laborers. Quarterly Jownal of Economics, 22, 210-232. Cipriani, C. J. (1967). Hedging in the Labor Market. Sowhem Econownic Jowmal, 33, 286-292.

Corocan, M. \& Duncan, G. J. (1.979). Work History, Labor Force Attachment, and Eamings Differences Bewwen Races and Sexes. The Joumal of Hunam Rossources. Educotion. Manpower and Welfare Policies, A(1), 3-20.

Dart, E. D., Argote, L., \& Epple, D. (1995). The Acquisition, Transfier, and Depreciation of Knowledge in Service Organizations: Productivity in Franchses. Martagemen Srience, 41. $1750-1762$

Dawis, S. J., Haltiwanger, J. C., \& Schuh, S. (1996), Jab Creation and Job Destruction. Cambrige MA: MIT-Press.

Dubin, 3. (1972), Obsolescence or Lifelong Education. Amevican Psychologist, 27. 486-498.

England. P. (1982). The Fanlure of Human Capital Theory to Explain Occupational Sex Segregation. The Journal of Human Resources, 17. 358-370.

Epple. D., Argote, L., \& Devadas, R. (1991). Organizational Leaming Curves." A Method for Investigating Intra-Plant Transfer of Knowledge Acquired Through Leaming by Doing. Organization Science, 2, 58-70.

Freeman, R. B. (1976). The Overedacated American. Cambridge, MA.

Green, F., Ashton, D., Burchell., B., Davies, B., \& Felstead, A. (2000). Are British Wonkers Becoming More Skilled? In: L. Borghans \& A. De Grip (Eds), The Overeducated Worker? The Economics of Skill Utilization (pp. 77-106). Cheltenham: Edward Elgar.

Greenhalgh, C. Stewart, M. (1987). The Effects and Determinants of Training Oxford Bulletin of Economics and Statistics, 49(2), $171-190$.

Groot L. F. M., \& De Grip, A. (1991), Technological Change and Skill Formation in the Barking Sector. Economics of Education Review, 10,57-71.

Hamermesh, D. S. (1987). The Costs of Worker Displacement. Quamenly Joumat of Economics. $102,5:-75$.

Holmann, A. G. (1972). On-The-Job "Training, Obsolescence, Options, and Retraining. Southern Ecomonic Jomal, $38(3), 414417$.

Holmann A. G. (1973». Skill Obsolescence and Training: Reply. Southem Economic Jowmal, $39(4), 648-649$.

Jacobson. L. S., LaLonde, R. J., \& Sullivan, D. G. (1993). Earnings Losses of Displaced Workers. American Economic Rewiew, 83(4), 685 -709.

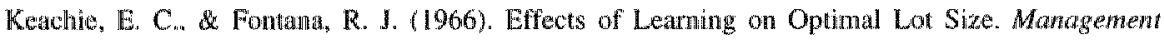
Situnce, 13\%, 1102-108.

Kim. M., \& Polaheck, S. W. (1994), Panel Estimates of Male-Female Eanings Functions. The Jowwat of Human Resources, 29(2), 406-428.

Kletzer. L. (1998), Job Displacement. Jownul of Econowic Perspectives, 12 . 115-136.

Krahn, H., \&owe, G. S. (1997). Literacy Unitization in Canadian Workphaces. Ottawa: Statistics Canada.

Longermann., P. A. (1996). The Benefits and Costs of Traning: A Comparison of Formal Company Training, Vendot Training, Outside Seminars, and School Based Training. Hamam Resonere Managenent, 35(3), 361-381.

Leuven, E, Oosterbeek, H. \& Van Optuen, H. (2000). Explaining International Differences in Male Wage Mequalities by Differences in Demand and Supply of Skill. Amsterdam.

Lillard, L. E., \& Tan, H. W (1992). Private sector training: Who gets it and what are its effects?. Reseanch in Labor Economics. 13, 11-62, 
Lilien. D. (1982). Sectoral Shifts and Cyclical Unemployment. Joumal of Polinical Econamy, 92 , $777-793$.

Lindbeck, A. \& Snower, D. (2000). Multi-Task Leaming and the Reorganization of Work, from Tayloristic to Holnstic Organization. Iownal of Labor Economics, 18, 353-376.

Lukasiewicz, J. (1971). The dynamics of science and engineering education. Engineering Education. $61,880-882$.

Machin, S., \& Van Reenen, J. (1998). Technology and Changes in Skill Strocture: Evidence From Seven OECD Countries. Qharnerly Jownal of Economics, 113, 1245-1279.

McDowell, J. M. (1982). Obsolescence of Knowledge and Career Publication Profites: Some Evidence of Differences among Fields in Costs of Intertupted Careers. The American Economic Rewiew, 72(4), 752-768.

Mincer, J. (1974). Schooling. Experience and Eartings. New York: Columbia Uniwersity Press. Mincer, J. (1989). Hwman Capital Responses to Techrological Change in the Labor Market (NBER Working Paper 3207). Cambridge MA: National. Bureau of Economic Research.

Mincer, J. Ofek, H. (1982). Interrupted Work Careers. Depreciation and Restoration of Human Capital Joumal of Human Resounces, 17, 3-24.

Mincer, J., \& Polachek, S. W. (1974). Fannily Investments in Human Capital: Earnings of Women. Joumal of Political Economy, 82(2), 76-108.

Mincer, J., \& Polachek. S. W. (1978). Women's Earnings Revisited. Jotmal of Haman Resounces, $13,118-134$.

National Skils Task Force (1999). Deliwering Skills for All (Second Report). Sudbury: Department for Education and EmploymentProlog.

Neuman, S. \& Weiss. A. (1995). On the Effects of Schooling Vintage on Experience-Eamings Profiles: Theory and Evidence. Europeam Economic Review, 39(5), 943-955.

Polachek, S. W. (1981). Occupational Self-selection: A Human Capital Approach to Sex Differences in Occupational Structure. Review of Economics and Statistics, 63, 60m69.

Rosen, $\mathrm{S}$. (1975). Measuring the Obsolescence of Knowledge. In: F. T. Juster (Ed.). Educarion, Income and Human Behavior (pp. 199-232). New York: Camegie Foundation fior the Advancement of Teaching \& National Bureau of Econonic Research.

Rosenow, E. C. (1971). Medical Knowledge Self-Assessment Programs. Paper presented at the Annual Meeting of the medical and Chirurgical Faculty of the State of Maryland, Battimore.

Sandel, S. H \& Shapiro, D. 1980). Work Expectations, Human Capital Accumulation and the Wages of Women. The Joumal of Human Resowress, 17(1), 335-353.

Su. T. T. (1973). Skill Obsolescence and Traning: Comment. Sowherv Econtmic Sownat. 3y(4). $645-648$.

Tugwell, R. G. (1931a). Occupational Obsolescence. Jownol of Adult Edhcatican, 1, 19-21

Tugwell. R. G. (1931b). The Theory of Occupational Obsolescence. Political seience Quarterity, 46. $1711 \mathrm{\omega m} 227$.

Van lmhoff, E, (1988). Age structure, education, and the transmission of technical change. Population Economirs, $1,167-181$.

Van Loo, J., De Grip. A., \& De Steur, M. (2001). Skills Obsolescence, Cáuses and Cures, International Joumal of Manpower, 22(1), 12』-137.

Van Loo, J. \& Semeijn, J. (200ll). Measuring Competences in School-Leaver Sunteys (ROA-RM 200 1/2E). Maastricht: Research Centre for Education and the Labor Market.

Watkins, K. E., \& Marsick, V. J. (1993). Sculpung the Learning Organization, Lessons in the Ar and Science of Systemic Change (1st ed.). San Francisco: Jossey-Bass Publishers.

Weisbrod. B. (1962). Education and Investment in Human Capital. Jowmal of Political Economy, $70.106-123$. 
Weiss, Y., Lillard, L. A. (1978\%. Experience, Vintage and Time Effects in the Growth of Eamings: Amencat Scientists. Joumal of Political Economy, 86, 427-447.

Wolf, E, (2000). Technology and the Demand for Skills. In: A. De Grip \& L. Borghaxs (Eds). The Owereducated Workes? The Ecomonics of skills Utilizaton (pp. 27-56). Cheltentan. U.K.: Eutward Elgar.

Wowd, A. (1994). Nowh-Soun Trade, Employment and Inequality: Changing Formus in a Skill Driven World. Oxword: Clarendon Press. 